\title{
Defined Activity Name Code
}

National Cancer Institute

\section{Source}

National Cancer Institute. Defined Activity Name Code. NCI Thesaurus. Code $C 93753$.

A coded value specifying the non-unique textual identifier for the activity. 